\title{
On translating the term acquis communautaire
}

\author{
A. Chebotaryova \\ Institute of Philology, Taras Shevchenko National University of Kyiv, Ukraine \\ Corresponding author. E-mail: annachebt@gmail.com
}

Paper received 30.01.18; Revised 04.02.18; Accepted for publication 05.02.18.

https://doi.org/10.31174/SEND-Ph2018-152VI45-04

Abstract. This article analyzes the term acquis communautaire within the purview of Translation Studies, paying special attention to each particular EU language. The material for the translational analysis emanates from IATE, where one can observe different variants of translation of this term. One of the main tasks of the analysis conducted is to expand horizons and generate an adequate variant of translation of this term in the Ukrainian language. It is of great importance when it comes to Ukraine, where the Association Agreement has finally come into force, calling for an ever-increasing demand for investigating and improving the level of bilateral communication and, therefore, the language of the EU, or, to put it linguistically, eurolect.

Keywords: translation, acquis communautaire, term, EU, eurolect, translation transformation, Ukraine, IATE.

The first thing that draws the attention of anyone who starts exploring EU-related legal materials is the term acquis communautaire. This is quite a puzzling notion for both common people (who try to catch the idea of what it might mean) and academics in the Translation Studies domain (who cudgel their brains over how to translate this term without being inordinately wordy or inadequately direct). The topicality of the research is seen in the recent developments in the EU-Ukraine relations culminating in the Association Agreement's entering into force on 1 September 2017. Hence, this is scholars, translators, and linguists as main language mediators who are responsible for successful communication between the parties. Additionally, the higher the Ukrainian language's clearness, the easier Ukraine will integrate into the EU legal domain at all levels.

The object of the research is the French term acquis communautaire, translated in all the official languages of the EU, whilst the subject of the study is the content and form of the term through the lens of its variants of translation.

The goal of this article is to conduct a comparative analysis of translation variants of the term acquis communautaire in all EU languages. Due to the fact that Ukraine still lacks its proper translation equivalent, the present article aims to fill this gap by generating and substantiating a Ukrainian variant of interpretation of the term $a c$ quis communautire. To reach this goals, the following objectives should be fulfilled: 1) to clarify the content of the eurolect-specific term acquis communautaire; 2) to contribute to domestic and European experts' discussions of defining and translating the EU's term.

The novelty of the study is determined, above all, by the fact that the EU-specific language, i.e. eurolect, is a promising and understudied phenomenon riddled with relevant terms whose equivalents still do not find their place in the Ukrainian language. So, finding an appropriate variant of translation of the term acquis communautaire is in order. The article has also a broad coverage of the theoretical and, especially, empirical aspects regarding the EU term representation in the Ukrainian language. A range of the following research methods were used: comparative translational analysis, descriptive and confrontational methods, the method of dictionary definitions and others.

First and foremost, this article seeks to answer the question of what does acquis communautaire stands for. In the EUR-Lex online glossary, this term means the body of common rights and obligations that are binding on all $\boldsymbol{E U}$ countries, as $\boldsymbol{E U}$ Members. It is constantly evolving and comprises:1) the content, principles and political objectives of the Treaties; 2) legislation adopted in application of the treaties and the case law of the Court of Justice of the EU; 3) declarations and resolutions adopted by the $E U$; 4) measures relating to the common foreign and security policy; 5) international agreements concluded by the EU and those concluded by the EU countries between themselves in the field of the EU's activities [11]. As it is put more clearly by Prof. Deborah Cao, a body of EU law is made up of:

1. primary legislation (the treaties);

2. secondary legislation derived from the treaties (regulations, directions, decisions, recommendations and opinions);

3. the case law of the European Court of Justice. [5, p. 150]

One more thing of great importance here is that Prof. Cao includes this term in the false friends of translators' list, pointing out that acquis communautaire means the body of EU laws, not acquis [5, 59 p.]. In this light, Emma Wagner, another famous translator who worked for the European Commission in Luxembourg for 30 years and coordinated the "Fight the Fog" EU campaign, shares her interesting standpoint, saying that EU insiders find this term to be a very convenient. But, unfortunately, it means nearly nothing to many outsiders (American readers do not understand it as well as European ones). She is also against using a specification technique in translation, suggesting that it is confusing that acquis communautaire spreads into derived expressions, such as "the Schengen acquis" (meaning the legislation and rulings adopted under the Schengen Convention) [29, p. 64].

True, the term acquis communautaire has unreasonably stayed unchanged in English as the language all the EU Member States and EU candidate countries are trying to follow. Another proof of its incorrect translation can be found in a special edition published by the European Comission under the title How to write clearly, where it is recommended to avoid and explain EU jargon words. To put it more clearly, one could have used the term body of EU law instead of the French term acquis communautaire. [12, p.12]

This is the case when the translation of the term acquis communautaire is of much greater importance then it might appear at first sight. Let us take a closer look at the European experience of translating this term. To enable 
such an exhaustive and comparative analysis we will make good use of mulilingual terminology database of the European Union IATE.

Generally speaking, we can divide all the variants of translation of acquis communautaire into 3 categories. The $1^{\text {st }}$ one can be subdivided into 2 subgroups: 1 . The first foresees the most appropriate way of transferring the eurolect's element in a target language (TL) by applying such translation techniques as naturalized borrowing, explicitation, equivalent translation, semantic modulation, naturalization, and omission; 2. The second foresees translation by using direct and/or partial borrowing. Such type of subdivision, however, is merely a matter of convenience. Moreover, some of the languages have up to 4 variants of translation, so one can find one and the same language in different categories regarding the ways of translating. The table below also demonstrates the level of reliability (R.) of a term, i.e. a term marked with 4 R. is very reliable and a term marked with $3 \mathrm{R}$. is reliable:

Table I.

\begin{tabular}{|c|c|c|}
\hline Language & $\begin{array}{l}\text { Term translated by naturalized borrowing, explicitation, equivalent translation, semantic modu- } \\
\text { lation, naturalization, and omission }\end{array}$ & $\begin{array}{l}\text { Term translated by } \\
\text { borrowing }\end{array}$ \\
\hline Bulgarian & $\begin{array}{l}\text { достижения на правото (4 R.) / достижения на правото на ЕО (3 R.): The word } \\
\text { достижения (achievements) is used plural form and the word правото is derived from the } \\
\text { word право (it means right, law [23]), and the abbreviation } E U \text { is omitted whilst the term is a } \\
\text { contextually bound one and relates to the EU instruments only; back-translation is achieve- } \\
\text { ments of the EU legislation. }[23,4]\end{array}$ & \\
\hline Danish & $\begin{array}{l}\text { gældende ret (4 R.) / gældende fællesskabsret (4 R.): The word gaeldende can be translated as } \\
\text { valid / applicable / existing, along the word ret that means law; back-translation is applicable } \\
\text { EU law or existing Community law [21] }\end{array}$ & \\
\hline Swedish & $\begin{array}{l}\text { gemenskapens regelverk (4 R.) / regelverk (3 R.) The word gemenskap is translated as commu- } \\
\text { nity [21], and the word regelverk means rule, set [19]; set of rules, legal framework, regula- } \\
\text { tions [21]. Back-translation: Community acquis [19], the (full) body of EU law [25] }\end{array}$ & \\
\hline Finnish & $\begin{array}{l}\text { yhteisön säännöstö (3 R.): the word säännöstö is translated as legal institution, code, set of } \\
\text { norms, rules and the word yhteisön means community. Back-translation: the EU set of norms } \\
\text { and rules [19] }\end{array}$ & \\
\hline German & $\begin{array}{l}\text { Besitzstand (3R.) / Besitzstand der Gemein-schaft (3R.) / gemeinschaftlicher Besitzstand (3 } \\
\text { R.). The word Besitzstand is fully pursuant to acquis, acquired rights [21], and the word Ge- } \\
\text { meinschaft means community. Back-translation: acquis, Community acquis }\end{array}$ & \\
\hline Greek & 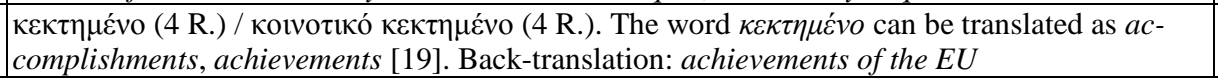 & \\
\hline Estonian & $\begin{array}{l}\text { ühenduse õigustik (4 R.) The word Õigustik translates as right, law and the word ühendus } \\
\text { correspondes to the words connection, alliance, community [22]. Back-translation: the EU law }\end{array}$ & $\begin{array}{l}\text { acquis communautaire } \\
\text { (3 R.) / acquis (3 R.) }\end{array}$ \\
\hline Croatian & $\begin{array}{l}\text { pravna stečevina (Europske unije) (4 R.). } \\
\text { The word pravna is translated as legal, the word stečevina correspondes to acquis and still can } \\
\text { be translated as core }[1 ; 8] \text { An official term which can be found in Translation Style Guide for } \\
\text { European Union Member States [25, p. 24] }\end{array}$ & \\
\hline Hungarian & uniós vívmányok (4 R.) Back-translation: the body of EU law [26] & $\begin{array}{l}\text { acquis communautaire } \\
\text { (4 R.) }\end{array}$ \\
\hline Italian & $\begin{array}{l}\text { realizzazioni comunitarie ( } 3 \mathrm{R} \text {.) The word realizzazioni means accomplishment (an accom- } \\
\text { plishment is something remarkable that has been done or achieved [7] }\end{array}$ & acquis (4 R.) \\
\hline Latvian & $\begin{array}{l}\text { Kopienas tiesību kopums ( } 3 \mathrm{R} .) \text { The word kopienas means community. The phrase tiesibu } \\
\text { kopums is translated as stock of existing legislation, sets of rules, rights [19]. Back-translation: } \\
\text { the EU set of rules and rights }\end{array}$ & acquis (4 R.) \\
\hline Slovenian & $\begin{array}{l}\text { pravni red (3 R.) / pravni red Skupnosti (3 R.) The word red means order, (set of) rules [23], } \\
\text { order [24], and the word pravni means legal [24]. The word skupnost means community as it is } \\
\text { shown in the example: Evropska skupnost (corresponds to European Union). Back-translation: } \\
\text { (the EU) legal set of rules and orders }\end{array}$ & \\
\hline Polish & $\begin{array}{l}\text { wspólnotowy dorobek prawny (Preferred) (3 R.) /dorobek prawny (3 R.) /dorobek prawny } \\
\text { Wspólnoty (3 R.) }\end{array}$ & acquis (3 R.) \\
\hline
\end{tabular}

The $2^{\text {nd }}$ category comprises 2 subgroups as well (see Table II): 1. Terms translated by partial borrowing, and dictionary equivalent - the instance when it is the word community to be translated into TL taking into considera- tion the linguistic traditions of whatever EU Member State (that is why, transposition is also applied); 2. Term is directly and/or partially borrowed:

Table II.

\begin{tabular}{|c|c|c|}
\hline Language & Term translated by partial borrowing, dictionary equivalent & Term translated by borrowing \\
\hline Czech & $\begin{array}{l}\text { acquis Společenství (3 R.) The Společenství has such dictionary equiva- } \\
\text { lents as communion, community [22] }\end{array}$ & acquis communautaire (3 R.) \\
\hline Lithuanian & $\begin{array}{l}\text { Bendrijos acquis (4 R.) / Bendrijos teisynas ( } 3 \text { R.) the word bendrijos is } \\
\text { derived from the word bendrija which, in its turn, has the meaning of } \\
\text { association, community and teisynas means code, statue [19] }\end{array}$ & acquis communautaire (3 R.) / acquis (4 R.) \\
\hline Latvian & Kopienas acquis (3 R.) & acquis (4 R.) \\
\hline Slovak & acquis Spoločenstva (3 R.) & acquis communautaire (4 R.) / acquis (3 R.) \\
\hline
\end{tabular}


The $3^{\text {rd }}$ category (see Table III) represents those languages which have 1 borrowed variant of translation (except for Dutch):

Table III.

\begin{tabular}{|l|l|}
\hline Language & $\begin{array}{l}\text { Term translated by direct borrowing (Irish, } \\
\text { Maltese, Dutch) and naturalized borrowing } \\
\text { (Italian, Portuguese, Spanish, Romanian) }\end{array}$ \\
\hline Irish & acquis communautaire (3 R.) \\
\hline Maltese & acquis communautaire (4 R.) \\
\hline Dutch & acquis communautaire (4 R.) / acquis (3 R.) \\
\hline Portuguese & acervo comunitário (4 R.) \\
\hline Spanish & acervo comunitario (4 R.) \\
\hline Romanian & acquis comunitar (3 R.) \\
\hline Italian & acquis comunitario (4 R.) \\
\hline
\end{tabular}

Now it is worth reviewing the Ukrainian variants of translation. In Glossary of Terms and Notions of the International and the European law, issued by the Legislation Institute of the Verkhovna Rada of Ukraine, the term acquis communautaire is translated as спільний доробок (back-translation from Ukrainian heritage, common work) and is defined as a set of legal norms, court decisions, doctrinal concepts, recommendations, agreements, etc. that apperared during the existence of European integration organizations; is the basis of the EU law and order and should be unconditionally followed by Member States and Applicant countries of the European Union. In the Ukrainian legal acts, the acquis communautaire is defined as the EU legal system, which includes (but is not limited to them) acts of EU law, adopted within the framework of the European Community, the common foreign and security policy in the area of justice and home policy. This concept is constantly evolving and encompasses the core, principles, and political objectives of the treaties establishing the European Union. [17, p.8]

In English-French-German-Ukrainian Dictionary of European Union terminology the term acquis communautaire is also translated as доробок (Спільноти) [10, p. 14]. The Ukrainian term доробок has become the epicentre of our attention, since it is almost the same in pronunciation, spelling, and meaning comparing with the Polish variant dorobek. True, if we look it up in the PolishUkrainian dictionary, we will find such variants as досягнення, доробок, надбання [16, p. 108]. Another dictionary represents a descriptive definition that sheds the light on the connotative meaning of the Polish term: 1. to, czego się ktoś dorobit własna praca (back-translation: something that has been done by a work); 2. ogót dziet stworzonych przez uczonego, pisarza, artyste itp.; też: ogól osiagnięć w jakiejś dziedzinie (back-translation: a set of works done by a scientist, a writer, an artist etc.; also, all the achievements in a certain domain $[9 ; 16, \mathrm{p} .125$, p. 383 , p. 524, p. 124]. In the Ukrainian dictionary, the term доробок means те, щзо зроблене, створене кимось (back-translation: done or created by someone) [1]. Although the French term acquis means that which has been acquired or achieved [18, p. 2], the word achievements is far from what is meant here and has a broader sense. As it is stated in Collins dictionary, the word achievement can be used in the meaning of: 1. something which someone has succeeded in doing, especially after a lot of effort; 2. the process of achieving something [7]. Therefore, it proves the fact of mistranslation in Ukrainian and makes it necessary to introduce the additional information in translation or explicitation technique.

According to Dr. Lucia Biel, a prominent researcher and translator in the domain of the EU translation, explicitation technique attempts to account for the recipient's knowledge gaps by explaining a concept which is absent in the target legal system or explicating central aspects of meaning which are responsible for the incongruity. She chooses a vivid example - that is, acquis communautaire - to demonstrate how it works. The preferred Polish equivalent is a descriptive equivalent wspólnotowy dorobek prawny (Community body of law), but the entry also allows for other explicitations: dorobek prawny Wspólnoty, dorobek prawny, as well as the borrowing acquis. In this case it would be difficult to explain, in terms of translation universals only, why the same EU term is explicated in one language and not in the other. Therefore, it may be methodologically flawed to separate explicitation from the language pair and institutional norms. [3, p.102]

Beside it, there exists 3 more Ukrainian variants of translation - acquis communautaire, acquis $6 C$, acquis Співтовариства; one can observe the way of translating as described in the $2^{\text {nd }}$ category above (see Table II).

Prof. Oleksandr I. Cherednychenko, a prominent Ukrainian scholar, linguist and translator, mentions in this light that the interpretation of acquis communautaire may require concretization in certain contexts since it is often referred to as the legal basis of the $E U$ [6, p. 401]. It truly is, however, we do not have it in translations.

The Ukrainian translation of EU terminology, according to Prof. Cherednichenko, as well as the EU in-house translation, demonstrates mostly the techniques of a full and partial calque of the term-combinations done with maintaining the number of its components. As is often the case with acquis communautaire, direct borrowing is the exception rather than the rule. [6, p. 402]

Dr. Darya S. Kasianenko, a Ukrainian translation researcher and translator specialized in the domain of EU translation, offers to leave the term acquis communautaire in translation as it is. Alongside with it, she argues that there is a need to provide the recipients with the "translator's explanatory note": under the concept acquis communautaire all the valid legal regulations, legislative acts and provisions are understood, which constitute the legislation of the European Union and the EU law and is mandatory for all EU Member States. Nowadays, as Kasianenko notes, the French term has already become rooted in the Ukrainian terminology of European law and has posed no problem for both the lawyers and the translators. [15, p. 148]

This is quite an interesting standpoint. Although she underpins the importance of descriptive translation techniques, Dr. Kasianenko still fails to represent a full and exhaustive definition. For instance, her translator's note lacks such essential concepts contained in acquis communautaire: 1. the term implies not only legal regulations, legislative acts and provisions but also court decisions; 2 . the fact that acquis communautaire is obligatory for all EU Member States is not true, since: a) what is obligatory for a Member State may not be binding to Candidate and Potential countries, and b) acquis inncludes soft-law in- 
struments which are known to be not binding; 3. although the term is rooted in the Ukrainian terminology, it is obscure to Ukrainians. As for EU experts, the challenging issue brought about by the difficulties in determining and translating such a dynamic term continues in the domains of Translation Studies and Law.

With respect to the later one, Prof. Victor I. Muraviov, a prominent Ukrainian scholar in the field of the EU law, suggests that this is not so essential to translate the term acquis - this is the content of the term that should be given attention. Since the acquis applies, first of all, to the Member States and States candidates for EU membership, it is not very necessary for the Ukrainian legislation to use the term "acquis" in its broad sense. It should also be taken into account that the content of the acquis is not something fixed - rather, it is permanently updated. [20, p. 70-71]

In general, Ukrainian translators agree on the direct borrowing which we cannot accept for a number of reasons when speaking about the clearness (transparency) of the term. First, it is self-evident that the EU philosophy is a human-centered one. Indeed, everything - that is made within the framework of the EU - revolves around a human being. It presupposes that any of the EU instruments should be written in a clear language, so that they can be easily readable and understandable for a human.

Second, it is not the argument that regarding the developing notion of eurolect, the presence of such terms as acquis communautaire in TL is natural. This term has nothing to do with the case of the internationally established legal language tradition to use such terms as mutatis mutandis, hereby, hereinafter, etc., without any changes in TL (unless it is a document designed for experts). Hence, it should definitely be translated.

Thus, with all the intricacies and nuances of the EU translation, we can suggest the right Ukrainian variants of translation of the term acquis communautaire with the help of explicitation technique: 1. законодавство (back translation: EU legislation); 2. чинні акти та судові рішення $C C$ (back translation: valid EU acts and court decisions). Returning to Dr. Kasianenko's definition, it is worth mentioning a very important word, that is, valid / Ukrainian variant: чинний (all the valid legal regulations). To my mind, it is the term that should be preserved in translation (as it is in Danish).

Taras Kachka, ex-deputy director of the State Department for Approximation of the Law (the Ministry of Justice of Ukraine) who has been working on the EUUkraine issues for many years, uses the term законодавство Свропейського Союзу, meaning асquі соттипиаtaire.[14]. If we go to the official website of the Verkhovna Rada of Ukraine, we can find out a definition of acquis communuataire: the EU legal system, which includes (although is not limited by them) acts of the EU legislation, adopted within the framework of the EU, common foreign and security policy, and cooperation in the area of justice and home affairs. [27]

In this respect, it is stressed in European Union: Foundations of politics, institutions and law edited by V. Pjatnitsky (cited in Muraviov's article Acquis of European Union and Legal Order of Ukraine, European studies, 2016) that parts of the acquis are regularly excluded from the legal instruments at the expense of those acts which have lost their effect. Taking into consideration similar viewpoints, I cannot but mention Annarita Felici, an associate professor of Translation (specialized in EU legal texts) at the University of Geneva, who uses the definition EU legislation in force to refer to the term acquis [13, p. 155]. Moreover, Emma Wagner suggests the same explicitation as well [29, p. 107].

The first Ukrainian variant shall be used when an international agreement or other highly specialized texts are under view (because of the limited space and a possibility to use special vocabulary). The second variant is a kind of translator's explanatory note and shall be used in any other cases or any EU texts designed for a wide range of people, one should translate the term with explicitation technique.

The last, but not least essential point to discuss in favor of the second proposed Ukrainian variant of translation, is that the suggested English translation of the acquis is body of EU law [12, p.12]. Obviously, there are no words connected with valid / existing, however, it is in the Ukrainian term. This situation can be easily explained by the fact that the English translation was invented for the EU Member States. In this respect, one should regard the status of Ukraine as a state that strives to become a part of the EU.

To sum it up, the exhaustive scrutiny explains in detail how the term acquis communautaire was translated in 24 official European languages and shows the criteria by which they have been categorized. Such an investigation pushes us towards a proper term identification in Ukrainian, which was identified and explained. The term acquis communautaire can easily be regarded as a so-called sui generis term in the EU domain - a hard problem of translators and jurists. Nevertheless, there exist 2 solutions to it: 1 . when an international agreement or other highly specialized texts are at issue, one should leave the term as it is or use its abridged form (because of the limited space and a possibility to use special vocabulary); 2 . in any other cases or any EU texts designed for a wide audience, one should translate the term with explicitation technique.

\section{REFERENCES}

1. ABBYY Lingvo-Online Dictionary [Electronic resource]. Access mode: https://www.lingvolive.com/ru-ru

2. Academic dictionary and thesaurus of the Ukrainian Language Explanatory Dictionary [Electronic resource]. - Access mode: http://sum.in.ua/s/dorobok

3. Biel, Lucja. Lost in the Eurofog: The textual fit of translated law / Lucja Biel. - Bern : Peter Lang, 2014. - 347 p.

4. Bulgarian online thesaurus [Electronic resource] - Access mode:

http://rechnik.chitanka.info/w/\%D0\%B4\%D0\%BE\%D1\%81
$\% \mathrm{D} 1 \% 82 \% \mathrm{D} 0 \% \mathrm{~B} 8 \% \mathrm{D} 0 \% \mathrm{~B} 6 \% \mathrm{D} 0 \% \mathrm{~B} 5 \% \mathrm{D} 0 \% \mathrm{BD} \% \mathrm{D} 0 \% \mathrm{~B} 8$ $\% \mathrm{D} 1 \% 8 \mathrm{~F}$

5. Cao, Deborah. Translating law / Deborah Cao. - Clevedon: Multilingual Matters, 2007. - $189 \mathrm{p}$.

6. Cherednychenko, Oleksandr I. Eurolect and problems of its translation / Oleksandr I. Cherednychenko // Movni ta kontceptualni kartyny svitu. - 2011. - vol. 39 - PP. 400-405.

7. Collins Online Italian-English dictionary [Electronic resource]. - $\quad$ Access mode: https://www.collinsdictionary.com/dictionary/italian- 
english/realizz azione

8. Croatian-English Dictionary [Electronic resource]. - Access mode:

http://www.englishcroatiandictionary.com/en/dictionarycroatian-english/ pravna

9. Dictionary of Polish language SJP [Electronic resource]. Access mode: dorobek;2453562.html

10. English-French-German-Ukrainian Dictionary of European Union terminology / [Editor-in-chief Ermolenko V.]. - Kyiv : K.I.S. Publisher, 2007. - 226 p.

11. Eur-Lex glossary of summaries [Electronic resource]. Access mode: http://eurlex.europa.eu/summary/glossary/acquis.html

12. European Commission. How to write clearly [Electronic resource]. - 2011. - Access mode: https://publications.europa.eu/en/publication-detail//publication/c2dab20c-0414-408d-87b5dd3c6e5dd9a5/language-en

13. Felici, Annarita. Multilingualism in EU Law: How Promulgation authenticates Equality / Annarita Felici // Comparative Legilinguistics. - 2010. - Vol.2 - PP.153-165

14. Kachka, Taras.Nova praktyka perekladu aktiv актів асquis communautaire / Kachka T., Movchan Yu. [Electronic resource] - Access mode: https://minjust.gov.ua/m/str_2405

15. Kasianenko, Darya S. Peculiarities of the Translation and Lexical Harmonization of the EU legislative acts in the context of EU integration of Ukraine : Ph.D. thesis in philology, speciality 10.02.16 - translation studies / Darya S. Kasianenko ; The state institution «South-Ukrainian National Pedagogical University named after K.D. Ushynsky». - Odesa, 2011. $-257 \mathrm{p}$.

16. Large Polish-Ukrainian, Ukrainian-Polish dictionary of modern business terminology / [Editor-in-chief Stanislav Domagalsky]. - Ternopil: Bogdan, $2010-1800$ p.

17. Law drafting: Glossary of Terms and Concepts on International and European Law / edited by Zaichuk V.O., Kopylenko O. L., et al. - Kyiv : Ukrainian School of Legislation at the the Legislation Institute of the Verkhovna Rada of Ukraine, 2005. - $160 \mathrm{p}$.

18. Miller,Vaughne. The EU's Acquis Communautaire Section
International Affairs and Defence Section / Vaughne Miller // UK House of Commons Library Research Papers. - London: House of Commons Library, 2011. - 4 p.

19. Multilingual online dictionary Globse [Electronic resource] Access mode: https://ru.glosbe.com

20. Muraviov, Viktor. Acquis of European Union and Legal Order of Ukraine / Victor Muraviov // European studies The review of European Law: Economics and politics. - 2016. Vol. 3 - PP. 65-74

21. Online Babla Database of Dictionaries [Electronic resource] - Access mode: https://www.babla.ru/

22. Online Czech-English dictionary [Electronic resource] Access mode: http://www.slovnik.cz/

23. Online dictionaries database Dict [Electronic resource] Access mode: https://www.dict.com

24. PONS Online Dictionary [Electronic resource]. - Access mode:

https://en.pons.com/translate?q=red\&l=ensl\&in=sl\&lf=sl

25. Portal for virtual dictionaries [Electronic resource] - Access mode: http://www.wordreference.com/sven/regelverk

26. Sfetcu, Nicolae. Translation Style Guide for European Union Member States [Electronic resource]. - 2015 - Access mode: https://books.google.com.ua/books?id=fs8BCAAAQBAJ\&pg $=\mathrm{PT} 24 \& \mathrm{lpg}=\mathrm{PT} 24 \& \mathrm{dq}=$ ste $\% \mathrm{C} 4 \% 8$ Devina + translate $\&$ source =b1\&ots=NIL3Lqfr9o\&sig=_XQ6B2-

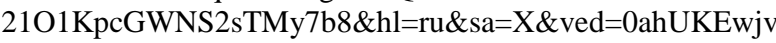
htC7

wJvYAhWEYVAKHdF3ARkQ6AEIUDAH\#v=onepage \&q= ste $\%$ C4\% $\%$ Devina $\% 20 \& \mathrm{f}=$ false

27. Terminology of legislation of Verkhovna Rada of Ukraine [Electronic resource] - Access mode: http://zakon0.rada.gov.ua/laws/term/33294

28. Translation Memory MyMemory [Electronic resource]. Access mode: https://mymemory.translated.net/en/Hungarian/English/v\%C3 $\%$ ADvm\%C3\%A1ny---v\%C3\%ADvm\%C3\%A1nyok

29. Wagner, Emma, Bech, Svend and Martínez, Jesus M. Translating for the European Union / Emma Wagner, Svend Bech, Jesus M. Martinez. - London and New York: Routledge, 2014 - 162 p.

\section{О переводе термина acquis communautaire}

\section{А. Чеботарева}

Аннотация. В статье проводится анализ термина acquis communautaire в рамках переводоведения, при этом каждому языку Европейского союза особое внимание уделяется. Материалом анализа служит база IATE, которая предлагает различные варианты перевода данного термина. Одним из ключевых заданий предлагаемого исследования является расширить горизонты понимания термина и воспроизвести на свет его адекватный перевод на украинском языке, поскольку вопросы, связанные с ЕС все больше набирают популярность на международной арене. Они представляют куда большее значение для Украины, где Соглашение об ассоциации наконец-то вступило в силу, призывая тем самым к постоянно растущему спросу на исследование и улучшение уровня двусторонних переговоров и, соответственно, языка ЕС или, выражаясь лингвистически, евролекта.

Ключевые слова: перевод, асquіs соттипаитаіге, термин, ЕС, евролект, переводческая транформация, Украина, IАTЕ. 